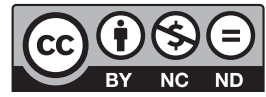

Estudos Teológicos foi licenciado com uma Licença Creative Commons Atribuição - NãoComercial - SemDerivados 3.0 Não Adaptada

http://dx.doi.org/10.22351/et.v58i2.3403

\title{
UM TEATRO "NÃO ESPETACULAR": PARA ALÉM DA CATARSE COLONIAL ${ }^{1}$ \\ A "non-spectacular" theater: beyond colonial catharsis
}

\begin{abstract}
Marcelo Ramos Saldanha ${ }^{2}$
Resumo: Neste ensaio, pretende-se abordar o teatro "não espetacular" de Augusto Boal, compreendendo-o como uma potente forma de superação da catarse do teatro aristotélico, entendido por nós como um teatro colonial, já que, até hoje, a poética de Aristóteles é a base de um modo de produção de cinema e televisão comprometido com um modelo de colonização estética. Assim, partiremos da crítica boalina à poética aristotélica, para, então, compreender como a estética do Teatro do Oprimido se constitui ainda como uma poderosa ferramenta para a gestação de novas estéticas, provenientes dos espaços limítrofes nos quais as pessoas que antes eram espectadoras passivas assumem sua teatralidade, construindo realidade e questionando a relação das verdades prontas, das quais antes eram apenas receptoras.
\end{abstract}

Palavras-chave: Poética. Aristóteles. Augusto Boal. Teatro-fórum. Curinga.

Abstract: In this essay the intent is to deal with the "non-spectacular" theater of August Boal, understanding it as a potent form of overcoming the catharsis of the Aristotelian theater, understood by us as colonial theater, since, to this day, Aristotle's poetics is the base of a form of production of cinema and television committed to a model of esthetic colonization. Thus, we begin with the Boal criticism of Aristotelian poetics, to, then, understand how the esthetics of the Theater of the Oppressed is still constituted as a powerful tool for gestating new esthetics coming from marginal spaces in which people who before were passive spectators, assume their theatrality, constructing reality and questioning the relation of ready truths of which before, they were mere receivers.

Keywords: Poetics. Aristotle. August Boal. Theater-forum. Joker.

1 O artigo foi recebido em 30 de julho de 2018 e aprovado em 29 de setembro de 2018 com base nas avaliações dos pareceristas ad hoc.

2 Doutor em Filosofia pela Universidade da Beira Interior, Portugal. Bolsista de pós-doutorado PNPD/ CAPES na Faculdades EST. Contato: marcelo.saldanha@gmail.com 


\section{Introdução}

Foi o diretor, dramaturgo e poeta alemão Bertold Brecht quem iniciou a polêmica entre seu teatro político e o teatro dramático teorizado por Aristóteles. Tanto que designou como aristotélica toda dramaturgia que não fosse dialética, estabelecendo uma nítida distinção entre elas e o seu Teatro Épico. Ao analisar o naturalismo e o drama psicológico presente na tragédia, Brecht criticou a importância desmedida que foi dada à emoção. Uma importância que não é desprovida de intenção, já que é por meio da emoção que se manipula o espectador e assim consegue-se manipular a realidade apresentada a ele. É dessa forma que a arte se torna um "sair do mundo" pela via emocional (catártica) para aceitar um outro mundo criado e apresentado por quem está habilitado a criar a dramaturgia. Para Brecht, com quem Boal concorda, o teatro aristotélico é, essencialmente, um teatro colonizador das subjetividades e o seu elemento catártico é o componente fundamental para que tal empreitada tenha êxito.

Em decorrência da abordagem brechtiana, a expressão teatro aristotélico ganhou caráter pejorativo, sendo a partir desse significado que Boal desenvolveu sua crítica ao sistema catártico aristotélico. Em seu livro Teatro do Oprimido e outras poéticas políticas, Boal criticou a passividade do espectador no teatro tradicional, entendendo-a como uma aliada das formas de opressão ideológica, chegando a descrever o teatro apresentado por Aristóteles em sua Poética como "um poderosíssimo sistema poético-político de intimidação do espectador"3, estabelecendo uma parede entre o palco e o público. A base do sistema aristotélico de coerção teatral está em intimidar o espectador por meio da empatia, inibindo sua participação no espetáculo e o conduzindo à reflexão, para assim eliminar suas "más" tendências ou tendências "ilegais". ${ }^{4}$ Esse persiste sendo o método não apenas do teatro convencional, mas também das produções de cinema e televisão, tanto para a veiculação tradicional como para os serviços de streaming, o que atualiza a poética aristotélica e justifica um debate atual sobre ela.

Este ensaio é um esforço de reflexão acerca do teatro boalino, em especial das técnicas do teatro-fórum e do sistema curinga em sua oposição ao sistema catártico, para compreender como tais técnicas, já em meados da década de 1970, fizeram do Teatro do Oprimido o que hoje chamaríamos de teatro decolonial, no sentido de ser um teatro que busca transcender a colonialidade e gerar novas e dinâmicas relações estéticas e políticas. Assim, sem fazer um exercício anacrônico de encontrar em Boal referências teóricas que lhe foram posteriores, partiremos da contundente crítica que esse fez ao sistema catártico da poética aristotélica, buscando compreender seus argumentos e a validade deles, para então demonstrar que dessa crítica nasceram técnicas teatrais que buscaram o fim do sistema hierarquizado de teatro.

\footnotetext{
3 BOAL, A. Teatro do oprimido e outras poéticas politicas. 2. ed. Rio de Janeiro: Civilização Brasileira, 1980b. p. 18.

4 BOAL, 1980b, p. 18.
} 


\section{A catarse aristotélica}

Para compreendermos a crítica boalina e o que entendemos aqui como superação da catarse aristotélica, vejamos um pouco acerca do que Boal denominou como "sistema trágico coercivo de Aristóteles", iniciando pela clássica definição da tragédia. Segundo Aristóteles, a tragédia consiste na

imitação de uma ação importante e completa, de certa extensão; [que] deve ser composta num estilo tornado agradável pelo emprego separado de cada uma de suas formas; na tragédia, a ação é apresentada, não com a ajuda de uma narrativa, mas por atores. Suscitando a compaixão e o terror, a tragédia tem por efeito obter a purgação dessas emoções ${ }^{5}$.

Nessa definição, encontramos os aspectos formais da tragédia e a apresentação de dois conceitos fundamentais para a compreensão do sistema trágico de Aristóteles: a catarse e a mimesis. O primeiro conceito é apresentado quando o filósofo fala de purificação (purgação) das emoções de compaixão e o terror como o resultado desejado da tragédia. Assim sendo, a qualidade da tragédia depende diretamente de sua capacidade de gerar essa purgação, um termo médico relativo a uma descarga afetiva com funções terapêuticas. Contudo, tal purificação não quer dizer libertação dessas mesmas emoções, já que o espectador pode vivenciar várias vezes a mesma experiência ao repetir o mesmo espetáculo. Seguindo sua explanação sobre o funcionamento psicológico da prática dramática, Aristóteles entendeu que ela segue uma estrutura humana universal, e enraizada nessa natureza, a tragédia tem por finalidade satisfazer certos fins do ser humano. Dessa forma, a natureza humana define quais sejam as boas tragédias, pois essas permitem ao ser humano encontrar o telos de sua natureza.

Através da narrativa de ascensão, queda e transformação de um personagem ideal (o herói), a tragédia, por meio da catástrofe, deverá conduzir o espectador ao reconhecimento de seus próprios erros e à purificação de sua hamartia 6 . Essa personagem distingue-se das pessoas ordinárias, sendo superior a elas, mas não ao ponto de não errar. É exatamente na falha trágica do herói que uma cadeia de acontecimentos o leva a vivenciar uma mudança de sorte e a sofrer um golpe que altera a condução inicial do drama, podendo levá-lo à desgraça profunda, como na tragédia do Édipo Rei, de Sófocles, citado por Aristóteles em sua Poética ${ }^{7}$. É assim que o espectador, vivenciando a dupla trajetória da personagem (primeiro como um caminho de sucesso e depois como um caminho de desgraça) e movido pelo sentimento reflexo de simpatia, experimenta o sofrimento do herói, identificando-se com a personagem, ao mesmo passo que mantém seu distanciamento em relação a essa.

5 ARISTÓTELES. Poética. Tradução de Ana Maria Valente. Lisboa: Fundação Calouste Gulbenkian, 2008. [Citado neste artigo sempre como Poética]. Poética 1449b, 25-30.

6 BOAL, 1980b, p. 50.

ARISTÓTELES. Poética, 1452a, 24. 
A finalidade pedagógica da tragédia não reside num princípio moralizador, do tipo que, por meio das narrativas da realização do mito, ensina o que não se deve fazer, mas consiste num aprender vivendo, isto é, aprender o que significa o agir em seu modo universal. Assim sendo, a tragédia não é imitação de pessoas, mas imitação das ações e da vida. ${ }^{8}$

Nessa relação reside o prazer trágico que se realiza num aspecto essencial da natureza humana, que é a tendência congênita para imitar. $\mathrm{O}$ conceito de mimesis atravessa toda a Poética, sendo uma noção encontrada na epopeia, na tragédia, bem como no ditirambo e na comédia. Na tragédia, a mimesis é lida diretamente com o viver, realizando-se na ação que comporta em si a boa e a má sorte, isto é, o risco. A mimesis sempre será a imitação de uma práxis. Há, nesse conceito, dois sentidos que são: a mimesis enquanto simulação, no sentido de exibir ou demonstrar algo, e como emulação, no sentido de seguir determinado referencial, como de um mestre, por exemplo. Diferente de Platão, que buscou excluir a expressão mimética do estado ideal por entender que a mimesis é um desfiguramento da verdade, uma imitação da imitação, Aristóteles entendia que ela não significa uma mera imitação, mas uma reprodução do real capaz de superá-lo, e nessa superação modificá-lo e recriá-lo. Como bem notou Boal, mimesis é

recriar esse movimento interno das coisas que se dirigem à perfeição. "Natureza" era esse movimento e não o conjunto de coisas já feitas, acabadas, visíveis. "Imitar", portanto, não tem nada a ver com "realismo", "cópia" ou "improvisação". E é por isso que Aristóteles podia dizer que o artista deve "imitar" os homens como deviam ser e não como são. Isto é, imitar um modelo que não existe"

Após a apresentação, mesmo que breve, desses dois conceitos fundamentais da Poética aristotélica, é importante salientar que, nela, cabe ao(a) espectador(a) o papel de ser passivo(a). Ele(a) é alvo da catarse, gerada nele(a) por meio da mimesis; afinal, na tragédia, a catarse é o próprio fim da mimesis. Por isso Boal afirma que "Aristóteles propõe uma Poética em que os espectadores delegam poderes ao personagem para que este atue e pense em seu lugar"10. É essa delegação de poderes que faz com que o sistema aristotélico delimite um distanciamento entre o palco e a plateia, o que acabou por definir uma forma de ser ator ou atriz e um modo de fazer teatro que, segundo Boal, nega à pessoa espectadora sua plena humanização como atuante-participante. Criou-se, nesse modelo teatral, um muro invisível entre o palco e a plateia. Para o teatrólogo brasileiro, foi a aristocracia quem aprofundou essa cisão por meio da transformação dos protagonistas, que "deixaram de ser objetos de valores morais, superestruturais, e passaram a ser sujeitos multidimensionais, indivíduos excepcionais, igualmente afastados do povo, como novos aristocratas" ${ }^{11}$. Esse procedimento criou

8 ARISTÓTELES. Poética, 1450a.

9 BOAL, 1980b, p. 27.

${ }^{10}$ BOAL, 1980b, p. 138.

11 BOAL, 1980b, p. 14. 
um muro entre os que têm algo a dizer e os que têm algo a aprender, sendo feita a apropriação do teatro pelas classes dominantes com a finalidade de promover a anulação do espírito revolucionário, conformando a plateia ao modelo de realidade que lhe é apresentado. Sempre haverá, nesse teatro, uma pessoa falante doadora de palavras e uma pessoa muda que lhe empresta os ouvidos, aos moldes da pedagogia bancária, o que leva Boal a afirmar que:

Só a transformação do espectador em protagonista impede que o teatro tenha uma função catártica. O espectador que é capaz de um ato liberador, ainda que tenha sido capaz de realizar esse ato apenas na "ficção" que é o teatro, é estimulado a realizá-lo também na vida real ${ }^{12}$.

A barreira nascida no sistema trágico-coercivo de Aristóteles começou a ruir com o teatro de Bertolt Brecht, que, mesmo delegando à personagem o poder de atuar em lugar da pessoa espectadora, reservou a essa "o direito de pensar por si mesma, muitas vezes em oposição ao personagem"13. Contudo, se tal barreira foi combatida, não o foi em plenitude, pois, embora no teatro brechtiano a pessoa que atua não ignore a presença da plateia, não faz dela uma interlocutora plena. Somente no teatro-fórum, instrumento do Teatro do Oprimido, essa quebra ocorreu de maneira eficiente, pondo por terra o muro da coerção. Boal mesmo demarca a diferença entre o seu teatro e o teatro brechtiano, notadamente quanto à necessidade da ação por parte da pessoa espectadora ao afirmar que

o que é insuficiente em Brecht é a falta de ação do espectador. Seu teatro é catártico, pois não basta que o espectador pense: é necessário que ele aja, acione, realize, faça, atue. $\mathrm{O}$ erro de Brecht foi não perceber o caráter indissolúvel do ethos e da dianoia, ação e pensamento - ele propõe dissociar e mesmo contrapor o pensamento do espectador ao pensamento do personagem, mas a ação dramática continua independente do espectador, que se mantém na condição de espectador ${ }^{14}$.

\section{E ainda:}

O que a Poética do Oprimido propõe é a própria ação! O espectador não delega poderes ao personagem para que atue nem para que pense em seu lugar: ao contrário, ele mesmo assume um papel protagônico, transforma a ação dramática inicialmente proposta, ensaia soluções possíveis, debate projetos modificadores: em resumo, o espectador ensaia, preparando-se para a ação real. Por isso, eu creio que o teatro não é revolucionário em si mesmo, mas certamente pode ser um excelente "ensaio" da revolução ${ }^{15}$.

12 BOAL, A. Técnicas Latino-Americanas de Teatro Popular. São Paulo: Hucitec, 1980a. p. 18.

${ }^{13}$ BOAL, 1980b, p. 126.

${ }^{14}$ BOAL, 1980a, p. 83.

15 BOAL, 1980b, p 138-139. 
A aversão de Boal ao modelo aristotélico levou-o a declarar que a pessoa espectadora, ser passivo, é menos que um ser humano, por isso é necessário re-humanizá-la, "restituir-lhe sua capacidade de ação em toda sua plenitude" . Por essa razão Boal insiste no caráter revolucionário de seu teatro e subverte o sentido da palavra teatro (thea-tron), pondo por terra as barreiras entre quem atua e quem assiste. É assim que o teatro "se transforma em arena, onde espectadores e atores, assumidos como artistas e cidadãos, fabricam um espetáculo que pulsa em permanente movimento, como a vida: práxis-tron"17.

Antes de prosseguirmos nosso aprofundamento no estudo da proposta boalina, é importante fazermos uma pergunta: será justa a crítica que Boal faz do teatro teorizado por Aristóteles? Embora creiamos que as críticas que o teatrólogo brasileiro faz à teoria teatral do estagirita são fundamentadas e corretamente expostas, não podemos deixar de pontuar que a maioria delas são derivadas do fato de Boal ter interpretado a Poética a partir das demais obras do filósofo, em especial a Política. Na leitura da obra aristotélica, Boal ateve-se em especial aos conceitos de felicidade (eudaimonia) e justiça (dikaiosyne), o que nos permite concluir que suas críticas são, em boa parte, exteriores à Poética. Dessa forma, mesmo acolhendo ou compreendendo as razões de tais críticas, é necessário ser justo com a obra aristotélica, apresentando aqui a sistematização das objeções feitas às críticas boalinas. Afinal, ir além da catarse aristotélica não é, necessariamente, negar a contribuição do filósofo grego, tampouco, como fez Brecht, homogeneizar os saberes teatrais anteriores ao seu teatro político, mas encontrar valor noutra relação entre a pessoa atuante e o tablado, pois é essencialmente nesse ponto que ocorre a superação do muro da coerção.

Inicialmente, é importante definir que o foco da Poética está, principalmente, na tragédia grega, onde o estagirita apresenta a descrição e análise da prática teatral existente em Atenas do século IV a.C. Será a partir dessa análise crítico-descritiva que Aristóteles formulará sua teoria normativa sobre a tragédia grega, chegando a caracterizar o que seja ou não uma boa tragédia. Isso posto, é necessário compreender que Aristóteles centra-se na construção de uma teoria normativa acerca do drama, em específico em seu aspecto psicológico, mas não de sua utilização política (mesmo que tal utilização possa ser deduzida por meio do contexto da obra do próprio filósofo). Sua teoria baseia-se numa concepção de ser humano circunscrito no tempo e no espaço, isto é, sua teoria é acerca do homem grego do período clássico. Assim sendo, os objetivos e a estética do drama grego não se relacionam anacronicamente com as concepções de sociedade e de ser humano idealizadas noutro contexto que não o grego clássico. Baseado nesse argumento, muitos acreditam que se pode criticar o uso contemporâneo da estética aristotélica, mas não se pode atribuir ao estagirita a criação dessa proposta de uso. Essa é a ideia defendida por Toruño-Haensly ${ }^{18}$, que chega ao ponto de acusar Boal de cometer erros lógicos ao interpretar a Poética. Para ele, ao

16 BOAL, 1980b, p. 180.

17 BOAL, A. A Estética do Oprimido. Rio de Janeiro: Garamond, 2009. p. 164.

18 TORUÑO-HAENSLY, R. La catarsis Aristotélica y la política dramatúrgica de Augusto Boal. In: BERISTÁIN, H.; VIDAL, G. R. (Org.). El Cuerpo, el sonido y la imagen. México: UNAM, 2008. p. 379-396. 
tratar da estética formulada pelo pai da lógica, Boal cometeu a falácia da generalização indevida ao não contabilizar em seu argumento que Aristóteles concebia que o drama poderia ser crítico de leis e de costumes, portando não sendo um simples instrumento de manutenção do status quo. Dessa forma, embora compreenda e exponha bem as teses aristotélicas, o teatrólogo teria se equivocado nas conclusões derivadas dessa exposição. Toruño-Haensly entende que faltou a Boal distinguir entre o projeto teórico de Aristóteles e o uso que se fez de sua teoria acerca do funcionamento psicológico do prazer dramático, que, por si só, não tem relação com seu uso político, já que a Poética traz em si um grande vazio quanto à abordagem política.

Realmente, é inquestionável que Boal não apenas leu a Poética com olhos de quem leu a Política, mas a leu influenciado pelas leituras críticas do contexto histórico no qual Aristóteles estava inserido. No entanto, não cremos, como também Boal não creu, que exista na Poética um tal vazio quanto à abordagem política, pois a despeito da intenção psicológica da descrição aristotélica, as tragédias, como salientou Hauser, são "francamente tendenciosas e não pretendem aparentar não serem. Tratam questões da política corrente e giram em volta de problemas, todos eles direta ou indiretamente relacionados com as questões candentes no momento" 19 . Na introdução de seu Teatro do Oprimido, Boal assinala que Aristóteles propõe "a independência da poesia (lírica, épica e dramática) em relação à política", devendo ser estudadas em separado, isso "porque possuem leis particulares, porque servem a distintos propósitos e têm diferentes objetivos" ${ }^{\prime 2}$. No entanto, Boal entende que não basta a declaração de intenções para que a realização siga o curso previsto por ele. Por isso, embora afirme que poesia e política são disciplinas completamente distintas, a própria teorização acerca dos aspectos psicológicos da tragédia parte de uma posição política. Se não podemos cometer o anacronismo de cobrar de Aristóteles uma concepção política característica do século XX, também não podemos cometer anacronismo igualmente danoso ao isolá-lo do contexto social e histórico ao qual o filósofo não deixou de estar atento, ou então, deslocar a Poética do restante do corpus aristotélico, ignorando que o autor permanece o mesmo, e que há um trânsito conceitual entre as obras, o que enfraquece o argumento de um erro lógico na crítica de Boal.

Mesmo que não acolhêssemos os argumentos boalinos acerca da catarse aristotélica, não poderíamos deixar de pontuar que o teatro derivado da análise que Aristóteles faz em sua Poética possui como elemento fundamental a barreira entre plateia e espectador, que não cai, mesmo que as críticas contrárias a Boal fossem incontestáveis. Portanto podemos ver que a superação da barreira característica da catarse aristotélica é um dos elementos mais originais do teatro popular proposto pelo dramaturgo brasileiro, que é a geração de outro sistema teatral, capaz de ultrapassar o uso político/opressor da catarse e, pautado em outra concepção de democracia e de humano, promover a construção de um palco realmente dialógico. A sua Poética do

${ }^{19}$ HAUSER, A. Historia social de la literatura y el Arte. Barcelona: Guadarraama; Punto Omega, 1978. p. 114. Para fortalecer seu argumento, Hauser remete-se ao castigo de Frínico por converter a tomada de Mileto em tema de uma peça, sem que o tratamento do tema correspondesse à opinião oficial.

${ }^{20}$ BOAL, 1980b, p. 18. 
Oprimido é essencialmente uma proposta para libertação, como define o próprio Boal, de um teatro no qual "o espectador se liberta: pensa e age por si mesmo"

Para entendermos como ocorre essa superação, será necessário compreender dois elementos fundamentais do arsenal estético-político do Teatro do Oprimido: o teatro-fórum e o sistema curinga.

\section{Teatro-fórum e o encontro com a fala}

Em 1973, ano em que participou da Campanha de Alfabetização Integral, denominada Projeto ALFIN, enquanto trabalhava com a técnica da dramaturgia simultânea, Augusto Boal percebeu a necessidade de quebrar com o domínio do palco por parte dos atores e das atrizes e fazer nascer outra forma de relação da plateia com o palco, a que chamou de teatro-fórum. Na dramaturgia simultânea, a companhia de teatro apresentava uma peça contendo um problema ao qual se queria encontrar uma solução. O espetáculo se desenvolvia até o ponto da crise, até o momento em que o protagonista devia tomar uma importante decisão. Nesse ponto, a peça parava e perguntava-se aos espectadores o que o protagonista deveria fazer. Cada um dava sua sugestão e as atrizes e os atores no palco improvisavam uma por uma, até que todas as sugestões se esgotassem. ${ }^{22}$ Como Boal mesmo define, nessa técnica os(as) espectadores "escrevem", simultaneamente ${ }^{23}$ com os atores e atrizes que representam.

No âmbito dessa prática, um fato emblemático marcou a ruptura que deu origem ao teatro-fórum. Uma mulher enganada por seu companheiro decidiu buscar ajuda no teatro proposto por Boal. Até então, o Teatro do Oprimido trabalhava apenas com problemas de cunho social ou econômico junto à plateia. Aceitando o novo desafio, Boal dirigiu os atores para que interpretassem a narrativa da mulher e, no ponto crítico vivido pela protagonista, interpelou a plateia na busca de uma solução. Após a interpretação das muitas opções advindas das pessoas espectadoras, uma mulher, definida por Boal como "corpulenta", deu sua opinião: "ela tem de deixar ele entrar, tem que ter uma con-

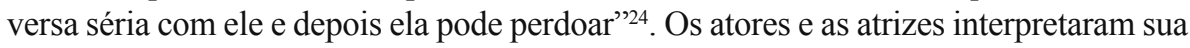
versão, mas a mulher manifestava corporalmente uma imensa inconformidade com essa atuação, que, segundo ela, não representava sua ideia. Diante dos olhares fulminantes da mulher, Boal questionou-a, disse que os atores e as atrizes tinham interpretado exatamente o que ela propora. Discordando do diretor, a mulher retrucou: "Não foi isso que eu disse. Eu disse que ela devia ter uma explicação clara, muito clara, e só depois, de... po...is..., só depois ela devia perdoar". Sem saber o que fazer, Boal propôs que ela subisse ao palco e encenasse a solução que achava melhor. Ela aceitou a sugestão e assim Boal narrou o resultado dessa experiência:

\footnotetext{
21 BOAL, 1980b, p. 181.

22 BOAL, A. O arco-íris do desejo: método Boal de teatro e terapia. Rio de Janeiro: Civilização Brasileira, 2002. p. 19.

23 BOAL, 1980b, p. 144.

${ }^{24}$ BOAL, 2002, p. 21.
} 
Iluminada, transfigurada, a senhora gorda estufou o peito, inflou-se toda e, com os olhos fulgurantes, perguntou: "Posso?" - "Pode!" Subiu ao palco, agarrou o pobre ator-marido indefeso, que era apenas um verdadeiro ator e não um verdadeiro marido e, além disso, magro e fraco, agarrou um cabo de vassoura e começou a bater-lhe com toda força, enquanto lhe dizia tudo o que pensava das relações entre marido e mulher. Tentamos socorrer o companheiro em perigo, mas a senhora gorda era mais forte do que nós. Finalmente, deu-se por satisfeita, colocou sua vítima sentada à mesa e disse: "Agora que nós tivemos esta conversa muito clara, muito sincera, agora você vai lá na cozinha e pega a minha sopa!"25.

Tal experiência demonstrou para Boal que "quando é o próprio espectador que entra em cena e realiza a ação que imagina, ele o fará de uma maneira pessoal, única e intransferível, como só ele poderá fazê-lo e nenhum(a) artista em seu lugar. Em cena, o ator é um intérprete que, traduzindo, trai. Impossível não fazê-10"26. A partir dessa experiência, o Teatro do Oprimido, que até então representava a ação por meio de atores e atrizes profissionais, passou a ser, também, teatro-fórum, no qual a pessoa espectadora converte-se em pessoa que atua. Assim, o teatro boalino passou a incluir em sua pedagogia, de forma mais intensa, a transitividade, a democracia e o diálogo, interrogando o espectador e esperando dele uma resposta, o que gerou um "espaço no qual se possa criar, aprender, ensinar, enfim, transformar"27. Nasce nesse momento a descolonização do poder de atuar.

No teatro-fórum, o termo espectador é substituído pelo termo espect-ator. O primeiro termo sugere a existência de um ser ativo e outro passivo, enquanto o segundo denota que a mesma pessoa pode assistir ou interferir na ação cênica. Boal não desconsidera a importância da profissão do ator, mas entende que "o teatro é uma atividade vocacional de todos os seres humanos"28.

Sendo um teatro-experiência, no teatro-fórum o processo de criação é mais importante que o resultado cênico, pois “o fórum é o espetáculo, o encontro entre os espectadores, que defendem suas ideias, e os atores, que contrapõem as suas" ${ }^{29}$. Enquanto se constrói a cena, os envolvidos na atuação, atores e espectadores, conseguem tomar consciência da mecanização do comportamento e, por meio de exercícios teatrais e da própria encenação comunitária, na qual os(as) profissionais da atuação não possuem controle, sentimentos e sensações represados podem encontrar espaço de fruição.

\section{O sistema curinga e o rompimento do muro}

No teatro-fórum, um facilitador, o ator curinga ${ }^{30}$, estimula a participação do público e entra em cena para substituir o oprimido e buscar alternativas para o pro-

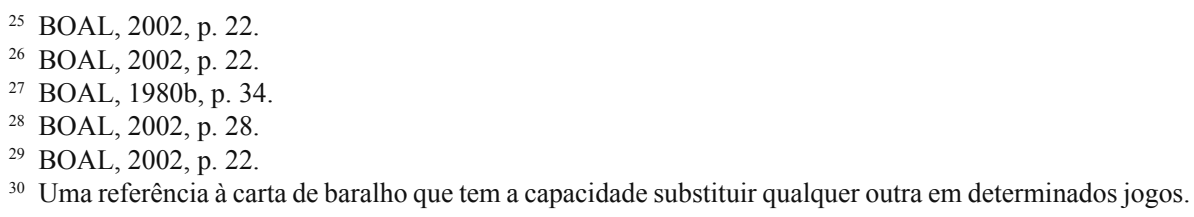


blema tratado na peça. O curinga atua como uma personagem onisciente e polimorfo, que interage na peça explicando, alterando a ação dramática, criando interações entre os atores e os espect-atores, permitindo que o segundo grupo participe na encenação. No exercício de sua função maiêutica, o curinga rompe a parede invisível que separa os dois grupos.

A realidade na qual essa personagem se enquadra é mágica, criada por ela mesma, à qual as demais personagens se adaptam. Ela poderá interpretar qualquer papel, inclusive o do protagonista, substituindo-o na ação. Podemos dizer que o curinga possui uma consciência cênica semelhante à do autor, estando acima das personagens, do espaço e do tempo das cenas, de tal forma que pode reunir em si todas as possibilidades teatrais. É importante salientar que, para atuar como curinga, o ator deve valer-se da interpretação stanislawskiana e seu comportamento em palco deve obedecer aos critérios da verossimilhança, buscando ser o mais autêntico possível.

O sistema curinga surgiu num dos maiores sucessos do Teatro de Arena, a peça Arena conta Zumbi $^{31}$, e foi aprimorado na montagem de Arena Conta Tiradentes ${ }^{32}$. Nessa obra, um importante episódio da história brasileira foi rediscutido utilizando-se de uma ótica moderna, de forma que o sistema curinga serviu como uma desorganização do espaço cênico, gerando um caos que permitia a emergência de uma nova estética. Essa técnica recebeu grande influência da ideia de reciprocidade entre educador e educando na pedagogia freiriana. Assim sendo, o curinga é, em si, um pedagogo e, como tal, comprometido com a superação do mutismo e do autoritarismo. Contudo, o teatro advindo dessa técnica não é um teatro pedagógico no sentido em que o é o teatro-propaganda, mas no sentido criativo, já que estimula o reinventar a realidade.

O uso de um personagem explicador já era conhecido do teatro mundial, contudo, diferente dessa técnica, o curinga distingue-se por seu caráter despudorado, exercendo sempre a função de oposição à atuação protagônica, como podemos perceber nas palavras de Boal:

O funcionamento da técnica [explicador] é escondido, envergonhadamente. Preferimos o despudor de mostrá-lo como é e para que serve. A camuflagem acaba criando um "tipo" de personagem muito mais próximo dos demais personagens do que da plateia: "Coros", "narradores", etc., são habitantes da fábula e não da vida social dos espectadores. Propomos o Curinga contemporâneo e vizinho do espectador. Para isto, é neces-

31 Encenada em 1965, Arena conta Zumbi foi escrita por Gianfrancesco Guarnieri e Augusto Boal, com direção de Augusto Boal e cenografia de Flávio Império, Luiz Kupfer, Maria Cecília C. Guarnieri, Maurice Capovilla, Rodrigo Lefèvre e Thomaz Farkas. Contou com música de Vinícius de Moraes e trilha sonora de Edu Lobo e Ruy Guerra. Essa peça teve a missão de sistematizar todas as experiências estéticas desenvolvidas pelo Teatro de Arena. É por isso que nela encontramos aspectos tanto do singular (o realismo) quanto do universal (os clássicos).

32 A peça Arena conta Tiradentes estreou em 21 de abril de 1967, tendo como tema a Inconfidência Mineira, vista aqui não em seu contexto histórico original, mas a partir dos acontecimentos da década de 1960, nomeadamente os eventos próximos, anteriores e posteriores, ao golpe militar de 1964. Foi escrita por Gianfrancesco Guarnieri e Augusto Boal, com direção de Augusto Boal, cenografia e figurino de Flávio Império, Iluminação de Orion de Carvalho, trilha sonora de Caetano Veloso, Gilberto Gil, Sidney Miller e Théo de Barros. 
sário o esfriamento de suas "Explicações"; é necessário o seu afastamento dos demais personagens, é necessária a sua aproximação aos espectadores ${ }^{33}$.

Relacionando-se diretamente com o público, toda vez que a peça tende à abstração e a plateia perde a relação empática com a personagem protagonista, o curinga exerce sua função de "contrapartida" à função protagônica, desempenhando de forma polivalente qualquer das personagens da cena e sobrepondo-se à limitação do próprio protagonista, quando esse fica preso à realidade naturalista. Ele pode adiantar ou fazer regredir qualquer cena, pode criar realidades mágicas, enfim, ele "é mágico, onisciente, polimorfo, ubíquo. Em cena funciona como menneur du jeu, raisonneur, mestre-de-cerimônias, dono do circo, conferencista, juiz, explicador, exegeta, contra-regra, diretor de cena, regisseur, kurogo, etc" ${ }^{\prime 34}$.

Com o sistema curinga, Boal fez uma clara opção no que tange à querela em torno da oposição de personagem-sujeito e personagem-objeto, como exposto por ele na discussão acerca da poética hegeliana e brechtiana. Segundo Boal, Hegel segue Aristóteles ao afirmar que a "ação dramática resulta do livre movimento do espírito do personagem" 35 , de forma que as ações concretas têm sua origem na subjetividade do personagem. Essa liberdade, desconectada das forças sociais, nos remete aos personagens que "menos sentem as pressões das necessidades materiais" "36, como os príncipes, que, livres da preocupação dos assuntos ordinários, podem exteriorizar livremente os movimentos do seu espírito. Brecht, enquanto teórico do teatro, segue um caminho antagônico ao de Hegel. Para ele, “o personagem é o reflexo da ação dramática e esta se desenvolve por meio de contradições objetivas, ou objetivas-subjetivas, isto é, um dos polos é sempre a infraestrutura econômica da sociedade, ainda que seja o outro um valor moral" 37 .

No Teatro do Oprimido, o curinga tem sua consciência cênica construída a partir das possibilidades que se montam a cada movimento. Sua liberdade é de outra ordem, por isso nem está esmagado pelas forças econômicas e sociais nem se vê ilusoriamente como sujeito absoluto. O curinga proclama a liberdade do personagem-sujeito. Sua atuação fala que a atividade dos indivíduos, sua praxis, é criadora de realidade. Essa atuação é entendida como princípio da ação, de modo que podemos afirmar que a liberdade do curinga não é ideologicamente representacional, como a de um príncipe desprovido de preocupações ordinárias ou de um operário massificado por um conceito objetivante, mas como de um indivíduo afetivo que, sentindo, cria, e criando, vive.

Como se pode bem notar, não foi interesse de Boal criar um teatro de espectadores, mas alterar o espaço cênico, fazendo dele um lugar de expressão do oprimido, de forma que esse possa ser um produtor de cultura e de novas formas de leitura da

\footnotetext{
33 BOAL, 1980b, p. 267.

34 BOAL, 1980b, p. 277.

35 BOAL, 1980b, p. 211.

36 BOAL, 1980b, p. 110.

37 BOAL, 1980b, p. 212.
} 
realidade. É dessa forma que o Teatro do Oprimido se tornou possibilitador de superação do hiato social, permitindo que a pessoa espectadora rompa com o papel passivo e passe a atuar na encenação, buscando, por meio do diálogo e da análise das estruturas, a superação da situação de opressão.

\section{Considerações finais: o espaço estético de um teatro decolonial}

Mesmo quando inconscientes, as relações humanas são estruturadas em forma teatral: o uso do espaço, a linguagem do corpo, a escolha das palavras e a modulação das vozes, o confronto de ideias e paixões, tudo que fazemos no palco fazemos sempre em nossas vidas: nós somos teatro. ${ }^{38}$

Com essa frase, parte do discurso proferido em 2009, no dia em que recebeu da Unesco o título de Embaixador Mundial do Teatro, Boal reafirmou sua crença de que o tablado é o espaço estético natural para o ser humano. É a primeira invenção do ser humano, que no processo de ver-se em situação "percebe onde está, descobre onde não está e imagina onde pode ir" ${ }^{39}$, isso permite ao ser humano criativo imaginar variantes para seu agir, estudar alternativas às ações de tal forma que "pode ver-se no ato de ver, de agir, de sentir, de pensar. Ele pode se sentir sentindo, e se pensar pensando"

Sendo natural, o tablado foi, contudo, desnaturado ao não permitir que a plateia crie teatro, tornando necessária a deturpação criativa da relação hierarquicamente estabelecida entre $\mathrm{o}$ ator e a atriz e a pessoa espectadora. Para superar essa desnaturação, o teatro-fórum e o sistema curinga, dentre as muitas técnicas que formam o "arsenal" do Teatro do Oprimido, emergem como formas de abertura do espaço cênico, gerando um lugar-momento estético em que a lógica colonial é suplantada. Aqui já não cabe a noção estética como regra do gosto concebida a partir da racionalidade ocidental, mas como um espaço imaterial, formado pelas interações criativas dos seres humanos. Há nesse lugar uma dimensão onírica, na qual a pessoa sonhadora não observa, mas "penetra nas suas projeções, atravessa o espelho, [de modo que] tudo se funde e confunde, tudo é possível”41. Nesse espaço, novas criatividades são celebradas de modo livre, de forma que não mais se reproduz a cisão entre a pessoa atuante e a plateia ou entre quem escreve e quem atua, mas ocorre o retorno à essência do teatro, que é "um tablado, dois seres humanos e uma paixão" ${ }^{\text {,2 }}$, como definia Lope de Vega. Assim, o teatro é entendido como uma arte vivida, no mínimo, entre dois seres, nunca um

\footnotetext{
38 "Even if one is unaware of it, human relationships are structured in a theatrical way. The use of space, body language, choice of words and voice modulation, the confrontation of ideas and passions, everything that we demonstrate on the stage, we live in our lives. We are theatre!' (BOAL, A. Message of Augusto Boal. World Theatre Day, 2009. Disponível em: <http://www.world-theatre-day.org/pdfs/WTD_Boal_2009. pdf>. Acesso em: 20 jun. 2018).

39 BOAL, 2002, p. 27.

${ }^{40}$ BOAL, 2002, p. 27.

${ }^{41}$ BOAL, 2002, p. 36.

${ }^{42}$ Lope de Vega apud BOAL, A. Hamlet e o Filho do Padeiro: Memórias Imaginadas. Rio de Janeiro: Record, 2000. p. 30.
} 
apenas, nunca de maneira autoritária. Afinal, todo teatro é, de uma forma ou de outra, comunitário, de forma que, mesmo no monólogo, o antagonista está implícito, mesmo que fisicamente ausente. Nesse palco, os seres humanos se encontram com a palavra-ação, que, como o Dabhar do Antigo Testamento, traz em si o duplo aspecto de ser operante e revelador. Já não é a palavra exógena da pedagogia dos depósitos, mas uma palavra afetiva, nascida em comunidade, no encontro dos humanos com as suas situações existenciais, com a sua própria palavra-mundo ${ }^{43}$. A palavra encontrada nessa relação dialógica entre os atuantes desse teatro-experiência é carregada de afeto, sendo palavra historicizada, encarnada, relacional, significada, por meio da qual ocorre a libertação dos corpos e das sensibilidades. Dessa dinâmica brota a poiesis do Teatro do Oprimido. Um teatro que, "devido a sua ênfase teatral como linguagem (para ser falado), mais do que como um discurso (para ser entendido), como um processo (a ser desenvolvido), mais que um produto acabado (a ser consumido)" ${ }^{\prime 4}$, consegue ver a pessoa oprimida como sujeito atuante e não como objeto da atividade teatral.

Quando a "face obscura da modernidade", em seu dinamismo mutante, se mostra hegemônica, impondo uma "universalidade" estética pautada nas lógicas coloniais de poder, a proposta decolonial torna-se uma exigência à arte enquanto arte-libertação. Nesse contexto, acreditamos que o Teatro do Oprimido, em seu pioneirismo como teatro que nasce dos entre-lugares, é potente para promover uma relação estética, comunitária e crítica na qual ocorre a construção de inéditos viáveis ${ }^{45}$. A partir desse espaço estético, as culturas emergem enquanto culturas da vida, do movimento, da fala, da criação e da diversidade, sendo que, a partir delas, se desnaturalizam as estruturas necrófilas da colonização, que cristalizavam na pessoa oprimida uma falsa noção de si, que são impostas à realidade das pessoas. No Teatro do Oprimido, a realidade é criação, por isso não pode ser imposta, mas apenas comunitariamente gestada. Gestada como arte grávida da vida.

\section{Referências}

ARISTÓTELES. Poética. Tradução de Ana Maria Valente. Lisboa: Fundação Calouste Gulbenkian, 2008.

BERISTÁIN, H.; VIDAL, G. R. (Org.). El Cuerpo, el sonido y la imagen. Mexico: UNAM, 2008. BOAL, A. Técnicas Latino-Americanas de Teatro Popular. São Paulo: Hucitec, 1980a. Teatro do oprimido e outras poéticas politicas. 2. ed. Rio de Janeiro: Civilização Brasileira, 1980b.

. Hamlet e o Filho do Padeiro: Memórias Imaginadas. Rio de Janeiro: Record, 2000.

$O$ arco-íris do desejo: método Boal de teatro e terapia. Rio de Janeiro: Civilização Brasileira, 2002. . A Estética do Oprimido. Rio de Janeiro: Garamond, 2009.

${ }^{43}$ FREIRE, P. A importância do ato de ler. São Paulo: Cortez, 1997. p. 11.

${ }^{44}$ BOAL, A. apud CHESNEY-LAWRENCE, L. Las teorías dramáticas de Augusto Boal. Teatro: Revista de Estudios Culturales / A Journal of Cultural Studies, v. 26, n. 26, 2003. p. 47.

${ }^{45}$ FREIRE, P. Pedagogia da Esperança: um encontro com a Pedagogia do Oprimido. Rio de Janeiro: Paz e Terra, 1992. p. 206. 
BOAL, A. Message of Augusto Boal. World Theatre Day, 2009. Disponível em: <http://www. world-theatre-day.org/pdfs/WTD_Boal_2009.pdf>. Acesso em: 20 jun. 2018.

CHESNEY-LAWRENCE, L. Las teorías dramáticas de Augusto Boal. Teatro: Revista de Estudios Culturales / A Journal of Cultural Studies, v. 26, n. 26, p. 25-55, 2013.

FREIRE, P. A importância do ato de ler. São Paulo: Cortez, 1997.

. Pedagogia da Esperança: um encontro com a Pedagogia do Oprimido. Rio de Janeiro: Paz e Terra, 1992.

HAUSER, A. Historia social de la literatura y el Arte. Barcelona: Guadarraama; Punto Omega, 1978. 